\section{Biological and environmental factors associated with risk of schistosomiasis mansoni transmission in Porto de Galinhas, Pernambuco State, Brazil}

\author{
Fatores biológicos e ambientais associados ao \\ risco de transmissão da esquistossomose mansoni \\ na localidade de Porto de Galinhas, Pernambuco, \\ Brasil
}

\section{Factores biológicos y ambientales asociados al riesgo de transmisión de la esquistosomiasis mansoni en la localidad de Porto de Galinhas, Pernambuco, Brasil}

\author{
Onicio Batista Leal Neto ${ }^{1}$ \\ Elainne Christine de Souza Gomes 1,2 \\ Fernando José Moreira de Oliveira Junior 1 \\ Rafael Andrade 1 \\ Diego Leandro Reis 1 \\ Reinaldo Souza-Santos 3 \\ Silvana Bocanegra 4 \\ Constança Simões Barbosa 1
}

\footnotetext{
${ }_{1}$ Centro de Pesquisas Aggeu Magalhães, Fundação

Oswaldo Cruz, Recife, Brasil. 2 Universidade Federal de

Pernambuco, Recife, Brasil.

${ }^{3}$ Escola Nacional de Saúde Pública Sergio Arouca, Fundação Oswaldo Cruz, Rio de Janeiro, Brasil. 4 Universidade Federal Rural de Pernambuco, Recife, Brasil.

Correspondence O. B. Leal Neto Centro de Pesquisas Aggeu Magalhães, Fundação Oswaldo cruz.

Av. Professor Moraes Rego $s / n$, Campus da UFPE, Cidade

Universitária, Recife, $P E$

50670-420, Brasil.

onicio@gmail.com
}

\begin{abstract}
Schistosomiasis has expanded to the coast of Pernambuco State, Brazil, where there are frequent reports of Biomphalaria glabrata snails and human cases of the disease. This study analyzes factors related to schistosomiasis transmission risk in Porto de Galinhas. A one-year malacological survey was conducted to identify biological, abiotic, and environmental factors related to the host snail breeding sites. Data analysis used Excel 2010, GTM Pro, and ArcGis 10. A total of 11,012 B. glabrata snails were captured in 36 breeding sites, and 11 schistosomiasis transmission foci were identified. A negative correlation was found between breeding site temperature and snail density and infection rate, and a positive correlation with $p H$ and salinity. The rainy season showed a positive correlation with snail density and infection rate. The study emphasizes the factors involved in the maintenance of schistosomiasis breeding sites, in light of persistence of this disease in Porto de Galinhas for more than 10 years.
\end{abstract}

Schistosomiasis; Biomphalaria; Spatial Analysis

\section{Resumo}

A esquistossomose se expande para o litoral de Pernambuco, Brasil, onde têm sido frequente os registros de caramujos Biomphalaria glabrata $e$ de casos humanos da doença. Este estudo apresenta fatores relacionados ao risco de transmissão da esquistossomose na localidade de Porto de Galinhas. Durante um ano, foi conduzido um inquérito malacológico para identificar fatores biológicos, abióticos e ambientais relacionados aos criadouros dos moluscos hospedeiros. Para análise dos dados, foram utilizados os softwares Excel 2010, GTM Pro e ArcGis 10. Foram coletados 11.012 caramujos B. glabrata nos 36 criadouros identificados, sendo diagnosticados 11 focos de transmissão da esquistossomose. Foi verificada correlação negativa entre a temperatura dos criadouros, densidade e taxa de infecção dos caramujos e correlação positiva para pH e salinidade. O período de chuva apresentou correlação positiva com a densidade e taxa de infecção dos moluscos. O estudo enfatiza os fatores envolvidos na manutenção dos criadouros da esquistossomose visto à persistência dessa doença na localidade de Porto de Galinhas há mais de 10 anos.

Esquistossomose; Biomphalaria; Análise Espacial 


\section{Introduction}

Schistosomiasis is considered one of the most prevalent infectious-parasitic diseases in the world 1,2 . This waterborne parasite infection has the helminth Schistosoma mansoni as the etiological agent and a heteroxenous life cycle, with humans as the definitive hosts and snails from genus Biomphalaria as the intermediate hosts. Brazil is the most heavily affected country of the Americas, with approximately 30 million persons exposed to the risk of acquiring schistosomiasis and an estimated 4-6 million individuals infected with $S$. mansoni 3,4 . The endemic extends from Maranhão to Minas Gerais, reaching 19 States ${ }^{3}$. Northeast Brazil is country's most heavily endemic region, with Alagoas, Sergipe, Bahia, and Pernambuco as the States with the highest prevalence of the disease 5 .

Pernambuco is the State of the Northeast with the third highest prevalence of human cases of the disease 6 and with the occurrence of two vector snail species, Biomphalaria glabrata and Biomphalaria straminea 7,8 . The natural habitat of these species consists of bodies of water with little current or stagnated water, preferentially in shallow areas of rivers, creeks, canals, and floodplains 9,10. On the State's coastline there have been various reports of these species colonizing non-natural and peridomiciliary aquatic environments: pools of rainwater, open-air wastewater, and flooded empty lots 11,12,13,14, thus demonstrating the snails' capacity to adapt to different habitats.

In Porto de Galinhas, Pernambuco State, schistosomiasis transmission has been reported since 200011 with numerous foci of B. glabrata in ditches, storm drains, and pools around households throughout the year 15. B. glabrata is known to be capable of shedding some 4,500 cercariae/ day 16 , so that areas harboring this type of vector can be considered to have high transmission potential.

Knowledge and analysis of the environmental conditions related to the occurrence of vector snails can provide valuable information on the maintenance of breeding sites/foci and consequently on the local model of schistosomiasis transmission. The use of some epidemiological analytical instruments (like spatial analysis technique with kernel intensity estimator) allow constructing environmental risk indicators as a simple alternative for analyzing the behavior of point (event) distribution patterns and estimating the point intensity of the process in the study regions, identifying risk areas for occurrence of the event, called "hotspots". From this perspective, the current study seeks to identify and an- alyze biological and environmental factors potentially associated with the occurrence of foci and breeding sites for B. glabrata, with the aim of determining the risk of schistosomiasis transmission on the coastal area of Porto de Galinhas.

\section{Material and methods}

The study was conducted in Porto de Galinhas, in the municipality (county) of Ipojuca on the southern coast of Pernambuco State, some $60 \mathrm{~km}$ from the State capital, Recife (Figure 1). This location was chosen on the basis of recorded $B$. glabrata breeding sites and the high number of schistosomiasis cases reported in the previous 10 years by the Schistosomiasis Laboratory and Reference Service at the Aggeu Magalhães Research Center, Oswaldo Cruz Foundation (CPqAM/Fiocruz). The study included all the communities in Porto de Galinhas with recorded B. glabrata breeding sites: Merepe III, Salinas, Socó, and Pantanal (Figure 1).

\section{Mapping of the location}

From May to June 2010, georeferenced mapping of the location was performed using a GPS (global positioning system) receptor (Vista Cx, Garmin, Kansas City, USA), configured in the UTM (Universal Transversa de Mercator) projection system, Datum SAD 69. The GPS data were later transferred through GPS TrackMaker Pro (Geo Studio Tecnologia, Belo Horizonte, Brazil), adjusting the polygons referring to blocks and demarcating all the breeding sites and their capture stations. This program also allowed saving the files (map of the location, distribution of the breeding sites and foci) in "shape" format, later used in the data's spatial analysis.

\section{Malacological survey}

Factors were defined as follows: (1) biological: data related to the vector snail breeding site (population density and S. mansoni infection rate); (2) abiotic: temperature, $\mathrm{pH}$, and salinity data recorded in the $B$. glabrata habitats; and (3) environmental: monthly rainfall in the municipality during the study period and classification of the breeding sites as permanent versus temporary. After identification of the breeding sites, monthly snail captures were performed, along with related abiotic and environmental data during a one-year period (July 2010 to June 2011).

The snails were captured with scoops and tweezers during 15-minute periods at demarcated stations in the recorded breeding sites. 
Figure 1

Reference map and study area. Porto de Galinhas, Ipojuca, Pernambuco State, Brazil, 2011.
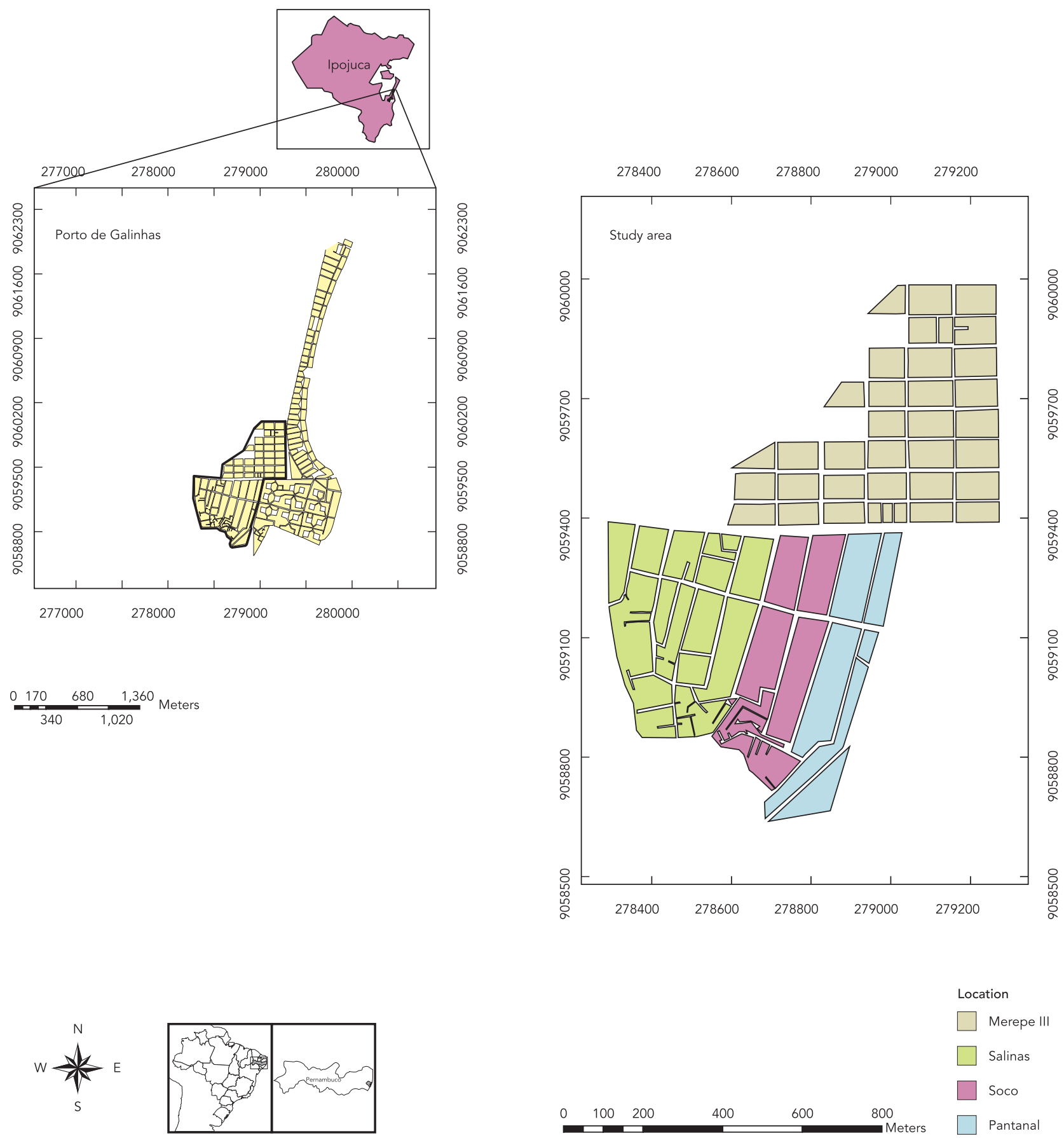

Location
Merepe III
Salinas
Soco
$\square$ Pantanal


Specimens were stored properly in moistened, ventilated plastic jars and identified for transportation to the Schistosomiasis Laboratory and Reference Service at CPqAM/Fiocruz. Ten percent of the snails were removed randomly from each batch for dissection and taxonomic species confirmation 17. For diagnosis of infection and identification of transmission foci, the snails were exposed to artificial light to shed the cercariae 18 . Negative snails were reexamined with the same technique 15 days after the first examination and those that remained negative were crushed (in groups of 12 between $15 \times 9 \mathrm{~cm}$ glass plates) for individual examination under a stereoscopic microscope, searching for S. mansoni sporocysts (larval stages) 19.

Snail density per breeding site was defined as the absolute number of snails captured at each breeding site per month. The natural infection rate (NI) or infectivity rate was calculated as the number of $S$. mansoni-positive snails divided by the total number of snails examined, according to the equation:

$$
\mathrm{N} 1=\frac{\text { Number of positive snails }}{\text { Total number of snails examined }} \times 100
$$

Thus, the monthly and annual infection rates for each breeding site/focus were calculated.

The following abiotic data were measured for all the breeding sites: temperature, $\mathrm{pH}$, and salinity, using the following instruments: column thermometer (Incoterm, São Paulo, Brazil), digital pH meter (PHTEK, Curitiba, Brazil), and refractometer (model 2011, Biobrix, São Paulo, Brazil); with scales of $0-50^{\circ} \mathrm{C}$; $0-14 ; 0-100 \%$ or parts per thousand (ppm) and specific gravity or density (1000-1070d), respectively. In parallel, field observation studies collected information on each breeding site: natural versus artificial; temporary versus permanent; use of the body of water (recreation, laundering, passage for local residents); distance from households.

Since there are no records that allow classifying the weather periods on the coastal area of Pernambuco based on precipitation rates, an analysis was performed of the historical rainfall series for the 10-year period from January 2001 to January 2011. The data were obtained from the databank of the Pernambuco Meteorology Laboratory (LAMEPE), available on the website of the Pernambuco Institute of Technology (ITPE; http://www.itep.br/LAMEPE.asp). These data were from the following rainfall stations on the coastal area: Ipojuca (Porto de Galinhas/IPA, Porto de Galinhas/PCD, Ipojuca); Goiana (Usina Maravilha); Tamandaré (IPA); Itamaracá (Itamaracá Station), and Jaboatão dos Guararapes (Ja- boatão dos Guararapes Station). In the municipality of Ipojuca, means were used from the data obtained from the three rainfall stations, since none of these stations had data for the entire period. The data from the Porto de Galinhas/IPA and Porto de Galinhas/PCD stations are for 20012006 and those from the Ipojuca station are from 2006-2011. A statistical analysis was performed for the total monthly rainfall variables, using the mean, standard deviation, coefficient of variation, kurtosis coefficient, and asymmetry coefficient. The data were used to construct a graph to define and group the weather periods in the study region.

Analysis of the correlation between snail density and monthly infection rate with the weather periods defined for Porto de Galinhas considered the monthly rainfall rates from June 2010 to May 2011, which were also obtained from the "Ipojuca" collection base, LAMEPE. The choice of the rainfall rate from the previous month for evaluation of the snail population density was based on the latter's life cycle $(1$ month $=$ egg $\rightarrow$ adult snail $\rightarrow$ egg), considering that for rainfall to influence snail density it is necessary to have rained during the previous month.

The correlation between snail density and monthly infection rate was also analyzed with the monthly means of the abiotic parameters measured in the breeding sites (temperature, $\mathrm{pH}$, and salinity). These analyses used the Spearman rank correlation coefficient $\left(r_{s}\right)$ with $5 \%$ significance, since it proved more adequate for analysis of a small sample, given that it overlooks the variable's fluctuation by turning it into ranks. All the correlation analyses used SPSS, version 13 (SPSS Inc., Chicago, USA), and the results were interpreted based on the following parameters: $0<\left|\mathrm{r}_{\mathrm{s}}\right|<0.25$ - very weak correlation; $0.25 \leq\left|\mathrm{r}_{\mathrm{s}}\right|$ $<0.5$ - weak correlation; $0.5 \leq\left|\mathrm{r}_{\mathrm{s}}\right|<0.75$ - moderate correlation; $0.75 \leq\left|\mathrm{r}_{\mathrm{s}}\right|<0.9$ - strong correlation; $0.9 \leq\left|\mathrm{r}_{\mathrm{s}}\right| \leq 1$ - very strong correlation 20 .

The physical and chemical parameters of the Biomphalaria breeding sites were analyzed on site in order to guarantee the quality of their measurement.

\section{Spatial analysis of data}

Spatial risk analysis for snail population density and B. glabrata breeding site and foci infection rate used ArcGis 10 (Environmental Systems Research Institute, New York, USA) using kernel intensity estimation. The following parameters were used: "Quantile" data classification method (stratification) and bandwidth defined with adaptive radius, more adequate for analysis of local studies 21,22 , set at 230 meters for analysis of 
malacological data, parameters defined in a previous study 15 , with the area unit defined in $\mathrm{m}^{2}$.

\section{Results}

All the breeding sites were artificial, located in the peridomicile, consisting of rainwater in the form of pools, ditches, and flooded backyards. During the year of the malacological survey, 11,012 B. glabrata snails were captured in the 36 breeding sites identified in the study area. Of these, 11 were classified as schistosomiasis transmission foci since they harbored snails infected with $S$. mansoni, totaling 272 positive snails.

Table 1 shows the total number of captured snails, the number infected, and the infection rate by month.

The snail population density and monthly infection rate were correlated with the monthly means of the following abiotic parameters measured in all the B. glabrata breeding sites: temperature, salinity, and $\mathrm{pH}$. Temperature showed a strong negative correlation with density and a moderate negative correlation with monthly infection rate $\left(r_{s}=-0.809 / p=0.001\right.$ and $r_{s}=-0.549 /$ $\mathrm{p}=0.064$; respectively). Figures $2 \mathrm{a}$ and $2 \mathrm{~b}$ show that the density and infection rate were higher in the months with the lowest temperatures; in the months with the highest temperatures (November and December) the snail density and infection rate were zero or nearly zero. Figure

Table 1

Snail density, number of infected specimens, and infection rate by month. Porto de Galinhas, Ipojuca, Pernambuco State, Brazil, 2011.

\begin{tabular}{lccc}
\hline Month/Year & \multicolumn{2}{c}{ Snails } & $\begin{array}{c}\text { Infection } \\
\text { rate (\%) }\end{array}$ \\
& Captured & Infected & \\
\hline July/2010 & 3,747 & 153 & 4.08 \\
August/2010 & 2,768 & 56 & 2.02 \\
September/2010 & 471 & 17 & 3.61 \\
October/2010 & 493 & 6 & 1.22 \\
November/2010 & 3 & 0 & 0.00 \\
December/2010 & 0 & 0 & 0.00 \\
January/2011 & 140 & 2 & 1.43 \\
February/2011 & 146 & 0 & 0.00 \\
March/2011 & 66 & 0 & 0.00 \\
April/2011 & 433 & 3 & 0.69 \\
May/2011 & 1,470 & 23 & 1.56 \\
June/2011 & 1,275 & 12 & 0.94 \\
Total & 11,012 & 272 & 2.47 \\
\hline
\end{tabular}

$2 \mathrm{~b}$ shows that the infection rate remained high in the months of September and October, when the snail population density had already begun to decline and the breeding site temperatures had begun to increase. The $\mathrm{pH}$ and salinity showed a very strong positive correlation with density $\left(r_{s}=0.964 / p=0.000\right)$, as shown in Figures $2 \mathrm{c}$ and 2e. Meanwhile the positive correlation between infection rate and $\mathrm{pH}$ and salinity was moderate, with $r_{s}=0.679 / p=0.022$ (Figures 2d and 2f).

Abiotic data showed wide variation during the study period, demonstrating the versatility of B. glabrata in adapting and resisting to diverse environmental conditions, withstanding the ranges: temperature $23-34^{\circ} \mathrm{C}, \mathrm{pH}$ 6.3-9.7, and salinity $1000-1003 \mathrm{~d}$. Water is classified as fresh when less than or equal to $1000 \mathrm{~d}$ or $0.5 \%$ and brackish at $>1000 \mathrm{~d}$ or $0.5 \%$. The breeding sites in Porto de Galinhas show the survival of these snails (typical of freshwater) in environments with salinity reaching $4 \%$ o (7 times higher than for freshwater).

All the B. glabrata breeding sites and foci identified in the study area were classified as temporary breeding sites, since they were found dried up during the driest season (November to December 2010) (Table 1). This influence of the rainfall pattern was directly related to the snail population density and infection rate, as observed in the dry months, in which 3 captured snails (November 2010) were found in a process of "aestivation" in the mud hole left over from the breeding site. All the breeding sites were located on the streets or in the yards of homes, at most 10 meters from the latter, predisposing humans to exposure through accidental contact with the foci when walking along the streets or through the flooded yards.

To study the relationship between weather seasons and their impact on the snail population, the rainfall data collected on the coastal areas of Pernambuco were grouped into 2 categories: rainy season (March to August) and dry season (September to February). The months that varied significantly from the mean were: May and June (rainiest period) and October, November, and December (driest period).

Correlation of the snail population density and infection rates with the rainfall data showed strong and moderate positive correlations, with $r_{\mathrm{s}}=0.769 / \mathrm{p}=0.003$ and $\mathrm{r}_{\mathrm{s}}=0.513 / \mathrm{p}=0.088$, respectively. This association can be seen in Figures $2 \mathrm{~g}$ and $2 \mathrm{~h}$, representing the monthly variation in snail density, infection rate, and rainfall in the study area. The highest snail density was in the month of July 2010, followed by August 2010 . The dry months (September-February) clearly 
Figure 2

Relationship between Biomphalaria glabrata snail population density and infection rate and mean temperature, $\mathrm{pH}$, salinity and rainfall in breeding sites. Porto de Galinhas, Ipojuca, Pernambuco State, Brazil, 2011.

2a) Relationship between $B$. glabrata density and temperature

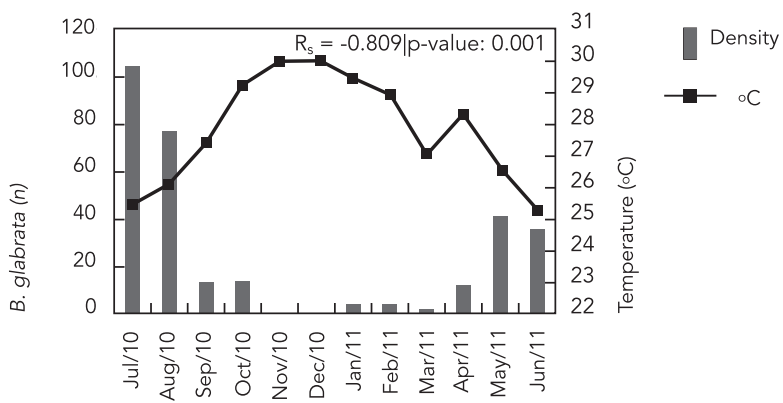

2c) Relationship between B. glabrata density and $\mathrm{pH}$

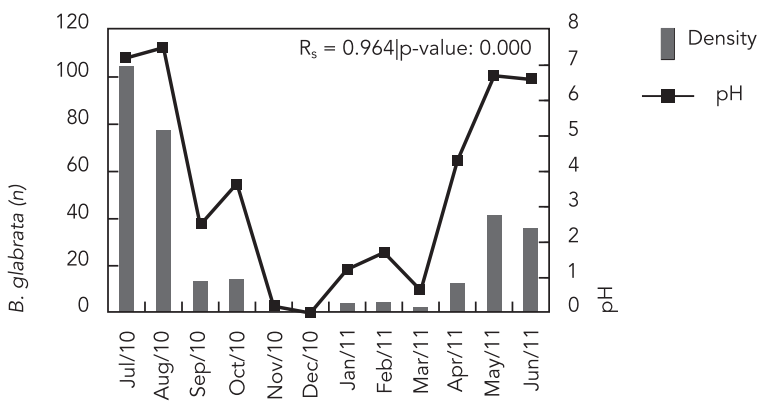

2e) Relationship between B. glabrata density and salinity

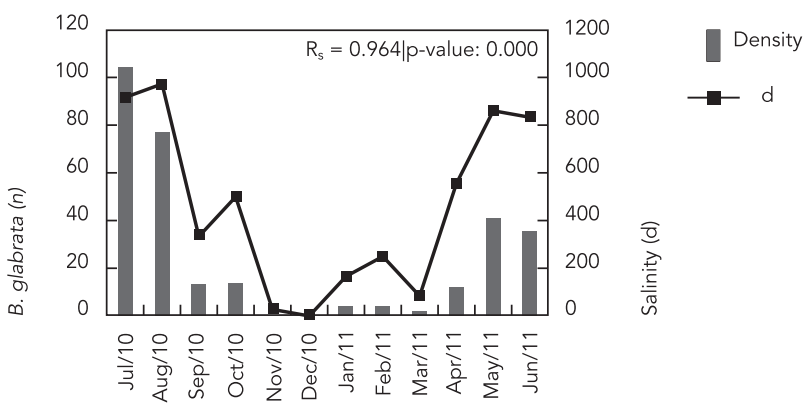

2b) Relationship between S. mansoni infection rate in B. glabrata and temperature

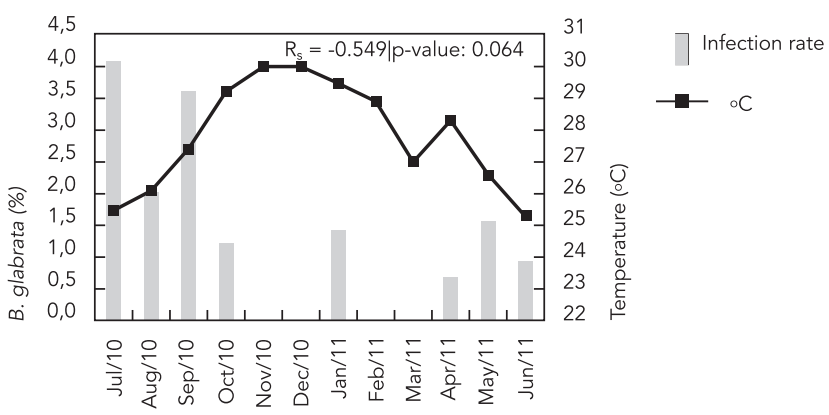

2d) Relationship between S. mansoni infection rate in B. glabrata and pH

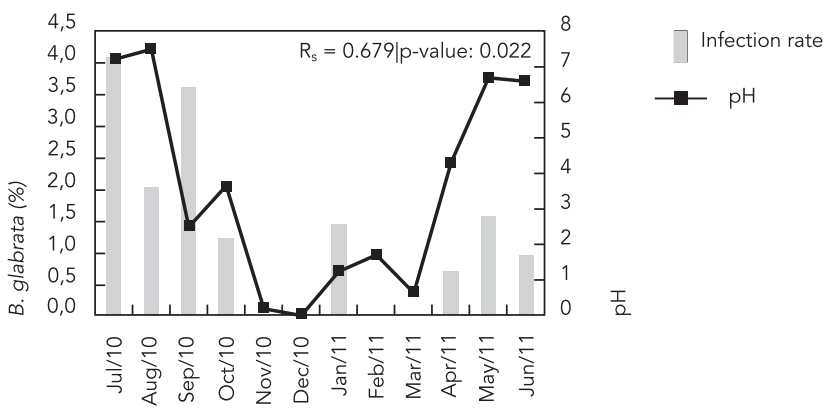

2f) Relationship between S. manosni infection rate in B. glabrata and salinity

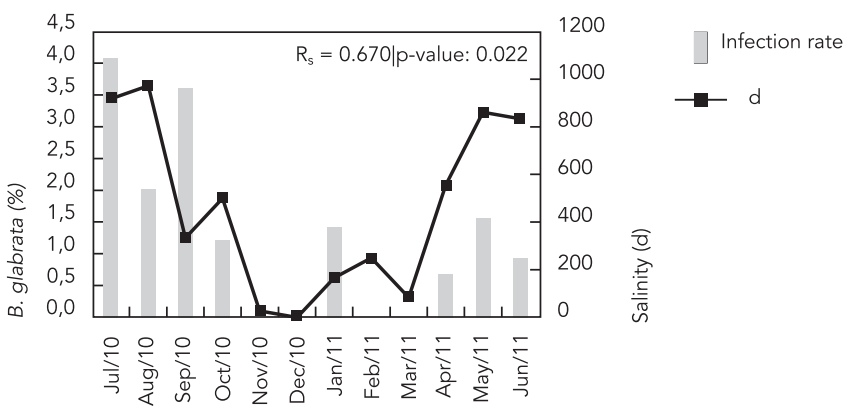

(continues) 
2g) Relationship between B. glabrata density and rainfall

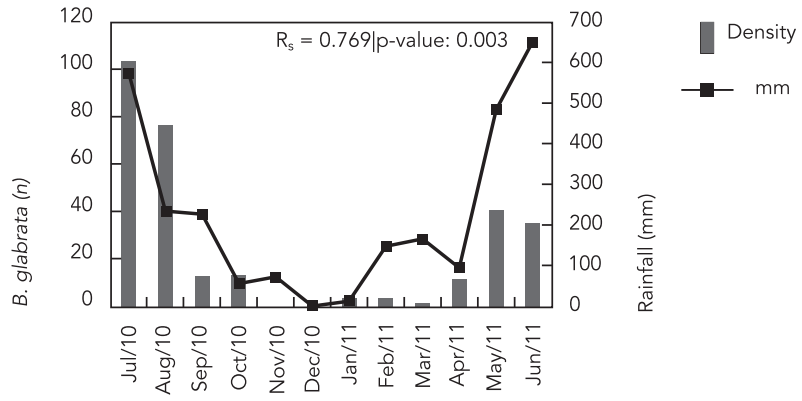

2h) Relationship between S. mansoni infection rate in B. glabrata and rainfall

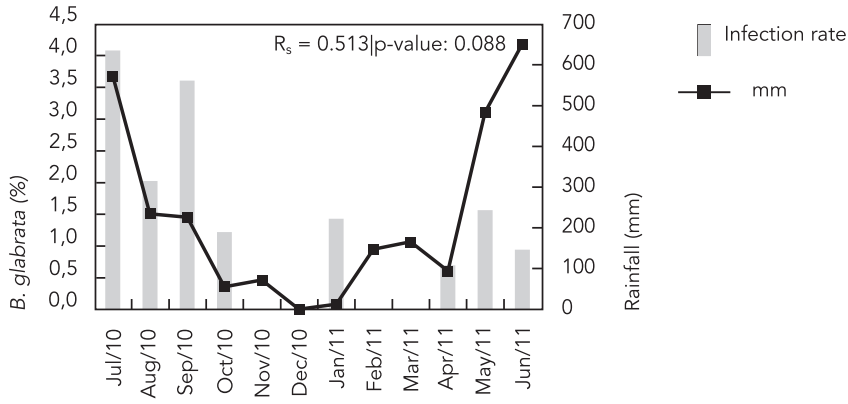

displayed low snail density. The start of the rainy season (March-August) was accompanied by progressive growth in the snail populations. The snail infection rate accompanied the seasonal variation in the dry and rainy periods (Figure $2 \mathrm{~h}$ ), but there was an extension of the high infection rates in the dry months of September and October. There was also an unexpected peak in the month of January, with two infected specimens (Table 1).

Figure 3 shows the spatial distribution of schistosomiasis breeding sites and foci by location in the study area, in addition to the respective snail population density and infection rates. Merepe III showed 6 breeding sites (1 focus); Salinas was the location with the most breeding sites and foci, 27 and 10, respectively; Socó and Pantanal recorded 3 breeding sites. The foci with the highest snail infection rates were breeding site numbers 7 (23.4\%) and 15 (49.1\%), closest to the flooded and brackish area of the mangrove. Although the majority of the infection rates were low, the high snail population density in the foci calls attention, as does the higher number of snails captured during one year of investigation.

Spatial analysis of the snail population density and infection rates per breeding site is shown in Figures 4a and 4b as kernel risk area maps. Density shows two hotspots: one more limited area in Merepe III and another more extensive area in Salinas, representing foci with increased potential risk of human contamination. A moderate risk extends to the south of Socó, reaching Pantanal. However, considering the positive infection of these snails with $S$. mansoni, the risk area is limited to Salinas, which showed the most foci for transmission of the disease.

\section{Discussion}

The graphs and trend analysis clearly reveal the influence of rainfall patterns on the vector snail population density and infection rates, highlighting how the existence and seasonal vigor of breeding sites and foci determine the periodicity of schistosomiasis transmission in Porto de Galinhas. The snail infection rates remained high until the start of the dry season, when the population density began to decline. The first captures after rains yielded adult snails that were already infected, showing that they are able to sustain the $S$. mansoni infection during aestivation, and that they are fit to shed cercariae and transmit the disease as long as weather conditions allow life in the breeding site.

The study's findings also indicate that rainfall patterns can directly influence the maintenance of abiotic factors (temperature, $\mathrm{pH}$, salinity) related to the B. glabrata breeding sites, providing ideal conditions for their installation, survival, and reproduction, thus involving an increase in the density and infection rates in the snails acting as intermediate hosts for this disease.

A previous study revealed the capacity of $B$. glabrata to survive in more alkaline and saltier environments than described in the literature 13 . Physical and chemical analysis of the breeding sites in the current study showed salinity indices up to $1003 \mathrm{~d}$, indicating that both the snail species and the $S$. mansoni strain are highly adapted to coastal environments with high salinity.

The highest vector snail density and infection rates were found in breeding sites 7 and 15, showing that they were the areas with the highest risk of human infection during the floods caused by 
Figure 3

Spatial distribution of Biomphalaria glabrata breeding sites and foci. Porto de Galinhas, Ipojuca, Pernambuco State, Brazil, 2011.

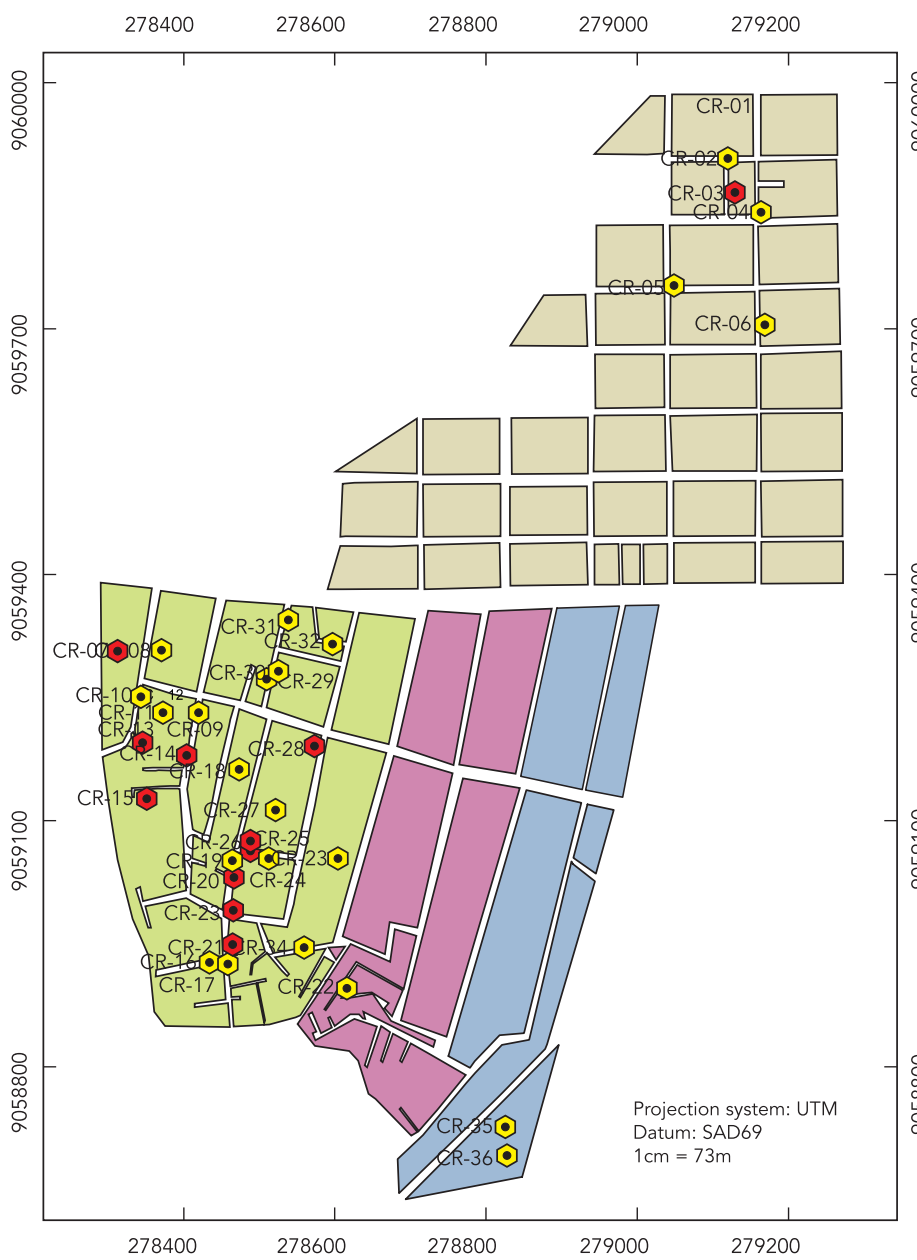

$0 \quad 4590 \quad 180 \quad 270 \quad 360$

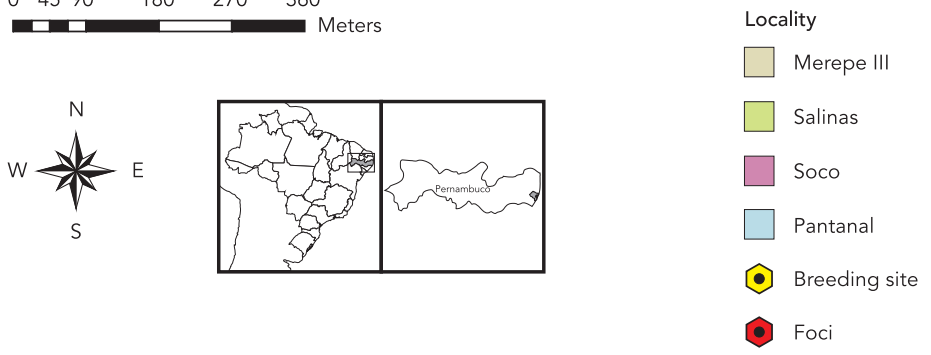

Foc

\begin{tabular}{|c|c|c|c|}
\hline Breeding site & Examined & Infected & Infection rate (\%) \\
\hline CR1 & 30 & 0 & 0.0 \\
\hline CR2 & 131 & 0 & 0.0 \\
\hline CR3 & 887 & 4 & 0.5 \\
\hline CR4 & 459 & 0 & 0.0 \\
\hline CR5 & 330 & 0 & 0.0 \\
\hline CR6 & 895 & 0 & 0.0 \\
\hline CR7 & 214 & 50 & 23.4 \\
\hline CR8 & 885 & 0 & 0.0 \\
\hline CR9 & 259 & 3 & 1.2 \\
\hline CR10 & 191 & 0 & 0.0 \\
\hline CR11 & 131 & 0 & 0.0 \\
\hline CR12 & 208 & 0 & 0.0 \\
\hline CR13 & 177 & 0 & 0.0 \\
\hline CR14 & 489 & 1 & 0.2 \\
\hline CR15 & 338 & 166 & 49.1 \\
\hline CR16 & 215 & 0 & 0.0 \\
\hline CR17 & 208 & 0 & 0.0 \\
\hline CR18 & 176 & 0 & 0.0 \\
\hline CR19 & 314 & 0 & 0.0 \\
\hline CR2O & 402 & 4 & 1.1 \\
\hline CR21 & 243 & 14 & 5.8 \\
\hline CR22 & 508 & 0 & 0.0 \\
\hline CR23 & 395 & 10 & 2.7 \\
\hline CR24 & 511 & 14 & 2.8 \\
\hline CR25 & 204 & 0 & 0.0 \\
\hline CR26 & 378 & 3 & 0.9 \\
\hline CR27 & 195 & 0 & 0.0 \\
\hline CR28 & 591 & 3 & 0.5 \\
\hline CR29 & 308 & 0 & 0.0 \\
\hline CR30 & 57 & 0 & 0.0 \\
\hline CR31 & 133 & 0 & 0.0 \\
\hline CR32 & 96 & 0 & 0.0 \\
\hline CR33 & 84 & 0 & 0.0 \\
\hline CR34 & 53 & 00 & 0.0 \\
\hline CR35 & 244 & 0 & 0.0 \\
\hline CR36 & 73 & 0 & 0.0 \\
\hline TOTAL & 11,012 & 272 & 2.5 \\
\hline
\end{tabular}


Snail density map [4a] and infection rate per breeding site [4b]. Porto de Galinhas, Ipojuca, Pernambuco State, Brazil, 2011.

4a) Snail density kernel map per breeding site

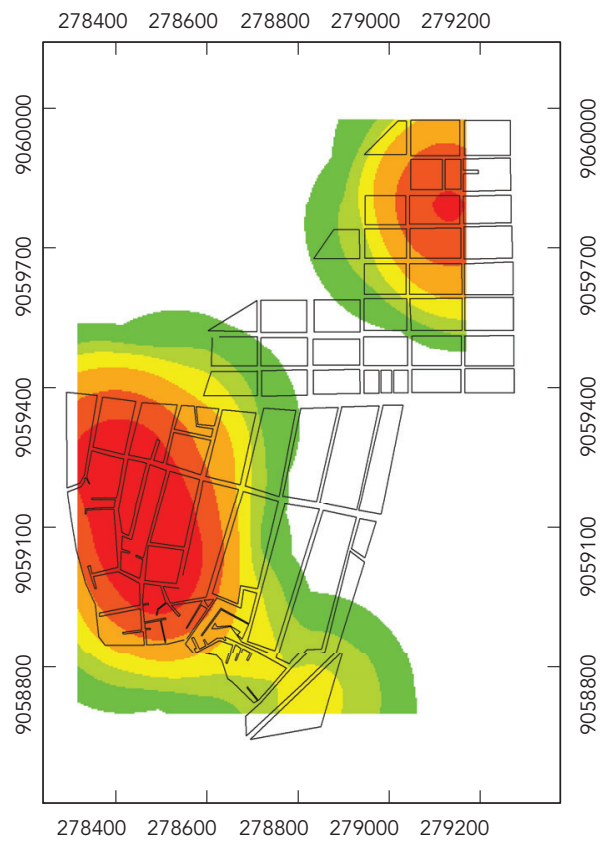

4b) Snail infection rate kernel map per breeding site

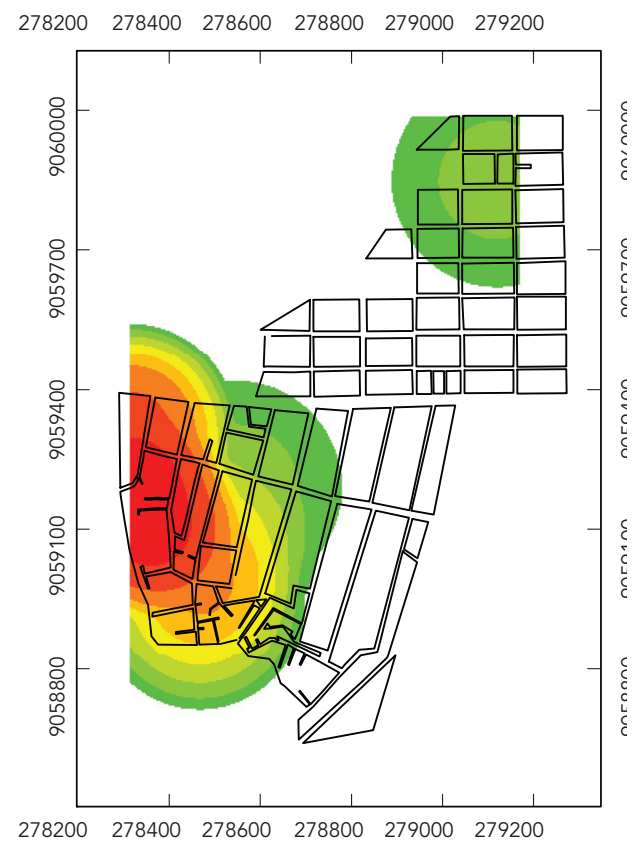

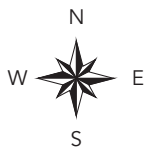

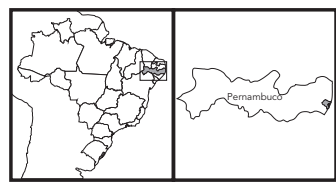

Projection system: UTM Datum: SAD69 $1 \mathrm{~cm}=100 \mathrm{~m}$

\begin{tabular}{llll}
0 & $70140 \quad 280$ & 420 & 560 \\
\hline
\end{tabular}

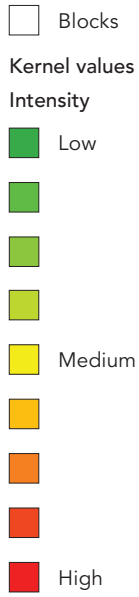

seasonal rains, causing mass exposure of individuals living close to these foci.

Salinas, the location with the majority of the schistosomiasis transmission foci, is the poorest and most heavily populated neighborhood in Porto de Galinhas, where the low-income population lives with precarious basic and en- vironmental sanitation, with open-air sewage, unpaved streets, and lack of a rainwater drainage system, the ideal conditions for maintenance of snail breeding sites. In association with these factors, the proximity to the mangrove area makes this neighborhood vulnerable to periodic floods when the adjacent Ipojuca River overflows. The 
floods carry both fecal matter (dumped in natura) and infected snails to other areas, facilitating the emergence of new disease foci and exposing local residents and beach-goers in other neighborhoods. The kernel maps (Figures $4 \mathrm{a}$ and $4 \mathrm{~b}$ ) show this location as the one with the highest risk of schistosomiasis transmission in terms of the odds of contact with transmission foci for the disease.

This bio-ecological situation poses some additional difficulties for potential biological and/ or environmental control strategies by health services in Porto de Galinhas. The fact that $B$. glabrata is surviving in aquatic environments with higher salinity levels than reported for this species in the literature indicates that these snails survive long enough to be perfectly adapted, and are thus fit to resist such strategies. An efficacious public health measure would be to build a rainwater drainage system that would reduce the snail population density and minimize mass exposure of individuals living close to these foci.

The study's results represent a major contribution to public health services, providing local health and environmental managers with precise information on the location, reproductive potential, and infective power of each schistosomiasis transmission focus. The results also define transmission peaks for the disease, map and categorize vector foci, allowing the design of specific and epidemiologically focused control strategies, meanwhile minimizing environmental damage insofar as possible. It is hoped that local public services will grasp this information and translate it into environmental and health improvements for the Porto de Galinhas community in order for the most beautiful location on the seacoast of Pernambuco to reverse its 10-year status as a prime site for the occurrence of schistosomiasis mansoni cases.

\section{Resumen}

La esquistosomiasis se expande hacia el litoral de Pernambuco, Brasil, donde han sido frecuentes los registros de caracoles Biomphalaria glabrata y casos humanos de la enfermedad. Este estudio presenta factores relacionados con el riesgo de transmisión de la esquistosomiasis en la localidad Porto de Galinhas. Durante un año se llevó a cabo una investigación malacológica para identificar factores biológicos, abióticos y ambientales, relacionados con los criaderos de los moluscos huéspedes. Para el análisis de los datos se utilizaron los softwares Excel 2010, GTM Pro y ArcGis 10. Se recogieron 11.012 caracoles $\mathrm{B}$. glabrata en los 36 criaderos identificados, siendo diagnosticados 11 focos de transmisión de la esquistosomiasis. Se verificó la correlación negativa entre la temperatura de los criaderos, densidad y tasa de infección de los caracoles, y la correlación positiva entre el $\mathrm{pH}$ y salinidad. El período de lluvia presentó una correlación positiva con la densidad y tasa de infección de los moluscos. El estudio enfatiza los factores involucrados en el mantenimiento de los criaderos de la esquistosomiasis, vista la persistencia de esta enfermedad en la localidad de Porto de Galinhas hace más de 10 años.

Esquistosomiasis; Biomphalaria; Análisis Espacial

\section{Contributors}

O. B. Leal Neto participated in the field data collection, spatial analysis, interpretation of the data, and writing of the paper. E. C. S. Gomes participated in the project's conceptualization, data analysis and interpretation, and relevant critical revision of the intellectual content. F. J. M. Oliveira Junior, R. Andrade, and D. L. Reis participated in the project's development, data analysis and interpretation, and writing of the paper. R. SouzaSantos participated in the project's conceptualization and development, data analysis and interpretation, and writing of the paper. S. Bocanegra participated in the project's development, data analysis and interpretation, and writing of the paper. C. S. Barbosa participated in the conceptualization and coordination, critical revision of the paper, and approval of the final version for publication.

\section{Acknowledgements}

The authors wish to thank the Schistosomiasis Reference Services at CPqAM/Fiocruz for the support provided during the fieldwork and CNPq and the Health Surveillance Secretariat of the Brazilian Ministry of Health for the research funding. 


\section{References}

1. Engels D, Chitsulo L, Montresor A, Savioli L. The global epidemiological situation of schistosomiasis and new approaches to control and research. Acta Trop 2002; 82:139-46.

2. Zhang Y, MacArthur C, Mubila L, Baker S. Control of neglected tropical diseases needs a long-term commitment. BMC Med 2010; 8:67.

3. Secretaria de Vigilância em Saúde, Ministério da Saúde. Guia de vigilância epidemiológica. 7a Ed. Brasília: Ministério da Saúde; 2010.

4. Lambertucci JR. Acute schistosomiasis mansoni: revisited and reconsidered. Mem Inst Oswaldo Cruz 2010; 105:422-35.

5. Amaral RS, Porto MAS. Evolução e situação atual do controle da esquistossomose no Brasil. Rev Soc Bras Med Trop 1994; 27:73-90.

6. Carvalho EMF, Coelho PMZ, Lenzi HL. Schistosoma mansoni e esquistossomose: uma visão multidisciplinar. Rio de Janeiro: Editora Fiocruz; 2008.

7. Carvalho OS. Intermediate hosts of Schistosoma mansoni in Brazil. Mem Inst Oswaldo Cruz 1992; 87:307-9.

8. Favre TC, Pieri OS, Zani LC, Ferreira JM, Domás GG, Beck LH, et al. A longitudinal study on the natural infection of Biomphalaria straminea and B. glabrata by Schistosoma mansoni in an endemic area of schistosomiasis in Pernambuco, Brazil. Mem Inst Oswaldo Cruz 2002; 97:465-75.

9. Barbosa FS, Barbosa CS. The bioecology of snail vectors for schistosomiasis in Brazil. Cad Saúde Pública 1994; 10:200-9.

10. Pieri O, Favre TC. Os moluscos transmissores. In: Barbosa CS, Favre TC, Quinino LRM, Gomes ECS, Leal Neto OB, Domingues ALC, et al., organizadores. Manual prático para o controle e diagnóstico da esquistossomose. Recife: Editora Universitária UFPE; 2008. p. 33-45.

11. Barbosa CS, Domingues ALC, Abath F, Montenegro SML, Guida U, Carneiro J, et al. Epidemia de esquistossomose aguda na Praia de Porto de Galinhas, Pernambuco, Brasil. Cad Saúde Pública 2001; 17:725-8.
12. Barbosa CS, Araujo KC, Antunes L, Favre T, Pieri OS. Spatial distribution of Schistosoma mansoni foci in Itamaracá Island, Pernambuco, Brazil. Mem Inst Oswaldo Cruz 2004; 99:79-83.

13. Silva PB, Barbosa CS, Pieri OS, Travassos A, Florencio L. Aspectos físico-químicos e biológicos relacionados à ocorrência de Biomphalaria glabrata em focos litorâneos de esquistossomose em Pernambuco. Quím Nova 2006; 29:901-6.

14. Souza MAA, Barbosa VS, Wanderley TNG, Barbosa CS. Criadouros de Biomphalaria, temporários e permanentes, em Jaboatão dos Guararapes, PE. Rev Soc Bras Med Trop 2008; 41:252-6.

15. Araújo KCGM, Resende APC, Souza-Santos R, Silveira-Junior JS, Barbosa CS. Análise espacial dos focos de Biomphalaria glabrata e de casos humanos de esquistossomose mansônica em Porto de Galinhas, Pernambuco, Brasil, no ano 2000. Cad Saúde Pública 2007; 23:409-18.

16. Neves DP, Melo AL, Linardi PM, Vitor RWA. Parasitologia humana. 12a Ed. São Paulo: Editora Atheneu; 2011.

17. Deslandes N. Técnicas de dissecção e exame de planorbídeos. Revista do Serviço Especial de Saúde Pública 1951; 4:371-82.

18. Kuntz ER. Effect of light and temperature on shedding of Schistosoma mansoni cercariae. Naval Medical Research Institute 1946; 7:16.

19. Coutinho JO. Índices de infestação natural dos planorbídeos pelas cercárias do Schistosoma mansoni na cidade do Salvador-Bahia. Anais da Faculdade de Medicina de São Paulo 1950; 25:29-53.

20. Finney DJ. Statistics for biologists. London: Chapman and Hall; 1980.

21. Lagrotta MTF, Silva WC, Souza-Santos R. Identification of key areas for Aedes aegypti control through geoprocessing in Nova Iguaçu, Rio de Janeiro State, Brazil. Cad Saúde Pública 2008; 24:70-80.

22. Lloyd CD. Local model for spatial analysis. $2^{\text {nd }} \mathrm{Ed}$. New York: Taylor \& Francis; 2006.

Submitted on 15/Mar/2012

Final version resubmitted on 19/Jul/2012

Approved on 11/Sep/2012 